\title{
Development of Iron Recovery Technique from Steelmaking Slag by Reduction at High Temperature
}

\author{
Kenji $\mathrm{NAKASE}^{1)^{*}}$, Akitoshi Matsui ${ }^{1)}$, Yoshie NAKAI ${ }^{1)}$, Naoki KIKUCh1 ${ }^{1)}$, \\ Yasuo Kishimoto ${ }^{2)}$ and Isshu Tetsuyama ${ }^{3)}$ \\ 1) Steelmaking Research Department, Steel Research Laboratory, JFE Steel Corporation \\ 2) Steel Research Laboratory, JFE Steel Corporation \\ 3) Energy \& Environment Group, Sumitomo Heavy Industries, Ltd.
}

Abstract: In order to develop a new recycling process of steelmaking slag, reduction of $\left(\mathrm{Fe}_{t} \mathrm{O}\right)$ and $\left(\mathrm{P}_{2} \mathrm{O}_{5}\right)$ in steelmaking slag at high temperature has been investigated. In this work, $50 \mathrm{~kg}$-scale experiments which simulated rotary kiln were conducted to investigate the separation behavior between slag and metal. Main results are as follows. (1) Molten iron was tapped out from the experimental furnace under the condition that more than $86 \%$ iron was reduced. (2) Weight of reduced iron did not affect the undefined ratio of phosphorus. (3) Common logarithm of phosphorus distribution ratio $\left(\log \mathrm{L}_{\mathrm{P}}\right)$, which was used as an index to explain the effect of slag composition, temperature and oxygen potential, correlates to the undefined phosphorus ratio. (4) In the experiments which simulated rotary kiln treatment, calculated phosphorus distribution ratio $\left(\mathrm{L}_{\mathrm{P}}\right)$ was smaller than that from experimental results. It can be said that the phosphorus transfer into the metallic phase decreased because the smaller interface between slag phase and metallic phase was obtained due to the slag/metal separation.

Keywords: slag reduction; dephosphorization from slag; basicity; thermodynamics.

\begin{tabular}{|c|c|c|c|c|}
\hline \multirow{2}{*}{ Experiments } & \multirow{2}{*}{$\begin{array}{c}\text { Initial } \\
\text { (mass\%T.Fe) }\end{array}$} & \multicolumn{3}{|c|}{$\mathrm{C} / \mathrm{S}$} \\
\hline & & $\sim 1.0$ & 1.5 & $2.0 \sim$ \\
\hline \multirow{2}{*}{$\begin{array}{c}\text { Crucible } \\
\text { (Previous research) }\end{array}$} & $2-5$ & $\diamond$ & & \\
\hline & $12-19$ & 0 & & 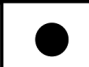 \\
\hline $\begin{array}{c}\text { Rotary kiln } \\
\text { (This research) }\end{array}$ & $15-28$ & $\triangle$ & $\triangle$ & $\Delta$ \\
\hline
\end{tabular}

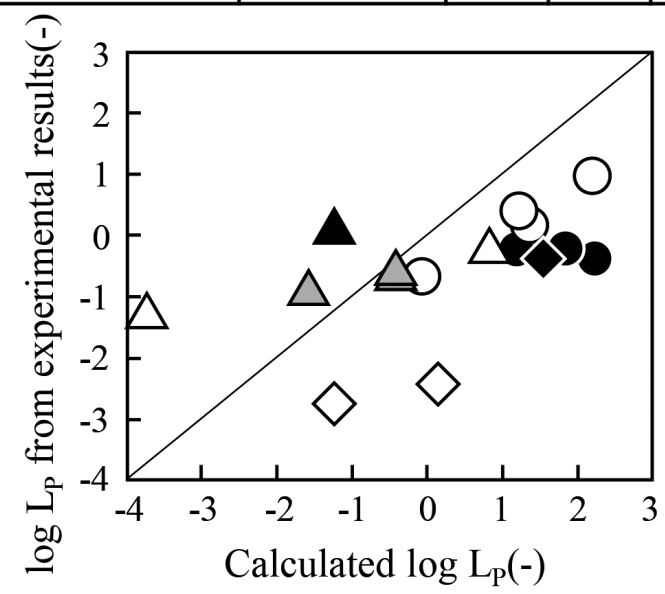




\title{
製鋼スラグ高温還元による鉄源回収技術の開発
}

\author{
中瀬 憲治 $^{1)}$ * 松井 章敏 ${ }^{1)} \cdot$ 中井 由枝 ${ }^{1)} \cdot$ 菊池 直樹 ${ }^{1)} \cdot$ 岸本 康夫 $^{2)} \cdot$ 鉄山 一州 $^{3)}$
}

Development of Iron Recovery Technique from Steelmaking Slag by Reduction at High Temperature

Kenji Nakase, Akitoshi Matsui, Yoshie Nakai, Naoki Kikuchi, Yasuo Kishimoto and Isshu Tetsuyama

\section{1. 緒言}

鉄鋼精錬プロセスに打いて発生する高炉スラグはおよ そ $290 \mathrm{~kg} / \mathrm{t}$-steel程度であり，セメント原料などに有効利用 されている。製鋼スラグはおよそ $120 \mathrm{~kg} / \mathrm{t}$-steel程度発生し， 土工用の埋め戻し材等に利用されている。製鋼スラグ中を 路盤材に利用するためには，未涬化石死による膨張崩壊性 を低減する必要がある。一方, 製鋼スラグ中の $\mathrm{Fe}, \mathrm{CaO}$ 源 の循環利用を目的として製銑プロセスへのリサイクル等の 効果的な処理, 利用の研究開発 ${ }^{1-3)}$ が実施されてきた。しか し，製銑プロセスへのリサイクルする際，製鋼スラグ中に 含有されるリンが，還元䨌囲気の高炉で溶銑に移行するた め, 鉄鋼製品の品質への悪影響が懸念されるため, 十分実 施されていない現状にある。

製鋼スラグからのリンの除去に関する研究については いくつかの報告がある。Shiomi ら ${ }^{4)}$ はスラグ塩基度 $(\mathrm{CaO} /$ $\mathrm{SiO}_{2}$ 重量パーセント比）が 1.1 ～1.2の合成スラグを黒鉛る つぼ内で溶融させてスラグの還元実験を行い，1773〜1873 $\mathrm{K}$ で脱リン率 68〜94\%が達成でき, スラグ中の $\mathrm{Fe}_{t} \mathrm{O}$ の還元 が $\mathrm{P}_{2} \mathrm{O}_{5}$ の還元に先行することを見出している。また，スラ グ中の $\mathrm{P}_{2} \mathrm{O}_{5}$ の炭素による還元反応速度が化学反応で律速 されるとしている。Takeuchi ら ${ }^{5)}$ はFe-Si合金共存下におけ る炭素による転炉スラグの還元実験を行い，リンが $\mathrm{P}_{2}$ ガス となって一部は溶鉄に溶け込み, 少なくとも $60 \%$ が気化除 去されて単体のリンとして回収できることを報告してい る。 Nagata ${ }^{6}$ は塩基度が 2.7 の予備処理スラグと黒鉛粉末を 混合し，黒鉛るつぼ内で溶融させて還元実験を行い，1896 〜 1938 K で70\%の気化脱リン率が得られたことを報告し ており，スラグの擋拌により反応界面積を増大させること で更なる脱リンの促進の可能性について言及している。

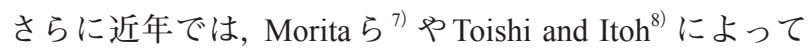
急速加熱を用いたスラグからの脱リンに関する研究も行 われている。また, Kubo ら ${ }^{9)}$ は溶銑脱リンスラグの構成相
が，鉄をほとんど含まないリン濃縮相と，リンをほとんど 含まない相に大別できることに着目し, 強磁場勾配を利用 して, スラグから両者を磁気分離する実験を実施し, 製鋼 スラグからのリン回収の可能性を検討している。

Matsui ${ }^{10)}$ は, 攪拌を付与した条件下で, 溶銑予備処理 スラグおよび転炉スラグ (塩基度 $=1.2 \sim 4.0$ ） の $\mathrm{Fe}_{t} \mathrm{O}, \mathrm{P}_{2} \mathrm{O}_{5}$ 還元挙動と温度の関係を調査し, スラグ中 $\mathrm{Fe}_{t} \mathrm{O}$ の活量が 扎よそ0.01以下まで還元された条件において，スラグ中 リンの除去率が $50 \%$ を超えることを報告している。また, Nakase ${ }^{11)}$ は, $\mathrm{Fe}_{t} \mathrm{O}$ 濃度の異なる製鋼スラグに対し, 擋挥 を付与した条件下で高温還元を行い, $\mathrm{Fe}_{t} \mathrm{O}$ 濃度の低いスラ グにおいて, 気相へ除去されるリンの割合が増加すること を報告している。

Harada ${ }^{12,13)}$ は, 直流アーク炉に保持した溶銑浴上に溶 融した転炉スラグを供給し, コークスで還元して Fe および $\mathrm{P}$ を溶銑浴に移行して回収する評価を行い, 溶銑浴のガス 擋拌無しでFe扎よびPの $90 \%$ 以上の還元が可能であるこ と, 処理中のスラグフォーミングの抑制が可能であること を報告している。

このように, 製鋼スラグ中の $\mathrm{Fe}_{t} \mathrm{O}, \mathrm{P}_{2} \mathrm{O}_{5}$ 還元挙動の研究 は多数行われているが, 還元により生成するメタル Fe と残 スラグの分離についての報告例は殆どない。本研究では, ロータリーキルンを模擬した数十 $\mathrm{kg}$ 規模の製鋼スラグ高 温還元実験を行い, 製鋼スラグから鉄とリンの還元, 分離 回収挙動について調査を行った。

\section{2. 実験方法}

住友重機械工業株式会社が所有するロータリーファー ナス ${ }^{14,15)}$ を用いて製鋼スラグの還元実験を行った。装置の 概略図を Fig.1に示す。 $\phi 1300 \times$ L500 mm の反応炉を， 0.4 $\mathrm{rpm}$ で回転しながら LPGバーナーで加熱を行った。反応炉 の回転方向を変更させることが可能であり, Fig.2 に示す様

2021年3月15日受付２021年5月14日受理（Received on Mar. 15, 2021; Accepted on May 14, 2021)

1）JFEスチール (株) スチール研究所製鋼研究部 (Steelmaking Research Department, Steel Research Laboratory, JFE Steel Corporation)

2) JFEスチール (株) スチール研究所 (Steel Research Laboratory, JFE Steel Corporation)

3）住友重機械工業 (株) エネルギー環境事業部 (Energy \& Environment Group, Sumitomo Heavy Industries, Ltd.)

* Corresponding author. E-mail: k-nakase@jfe-steel.co.jp, Address: JFE Steel Corporation, 1 Kokan-cho Fukuyama Hiroshima 721-8510 


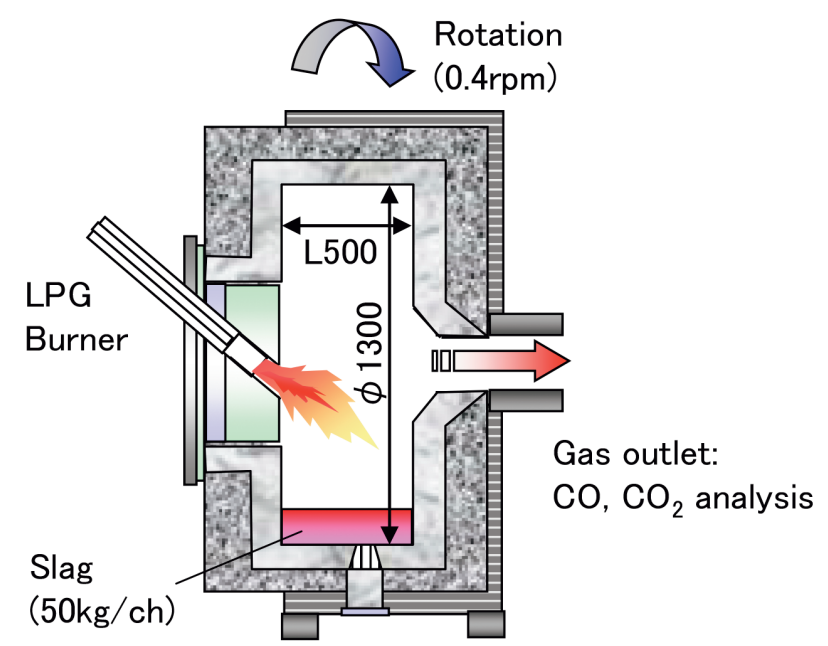

Fig. 1. Experimental apparatus. (Online version in color.)

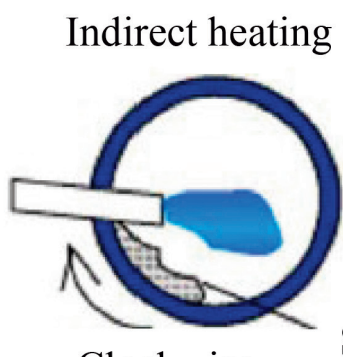

Clockwise

\section{Sample}

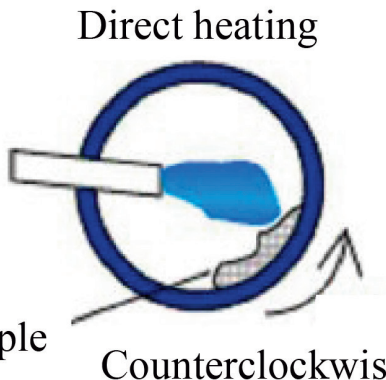

Fig. 2. Burner direction during experiment. (Online version in color.)
に,バーナー側から見て時計回りに回転させると, 炉内の サンプルはバーナー火炎が直接当たらず間接的に加熱さ れる。一方で，バーナー側から見て反時計回りに回転させ ると, 炉内のサンプルはバーナー火炎により直接加熱され る。実験中は常時, 熱電対により炉内温度を, 赤外式排ガ ス分析計により排ガス中の $\mathrm{CO}, \mathrm{CO}_{2}$ 濃度をモニターした。 LPG 流量は 12〜 $15 \mathrm{Nm}^{3} / \mathrm{hr}$ とし, 酸素源として空気および 純酸素を供給した。炉内温度が狙い温度となる様にLPG 流 量および酸素源として供給する空気と純酸素の流量およ び割合を変化させ，かつ炉内の CO濃度が $10 〜 15 \mathrm{vol} \%$ とな る様に空気および純酸素の流量を調節した。炉蓋には窒素 パージが可能な原料投入孔が存在し, 大気巻き込みを防止 しながら原料添加が可能である。また，炉体下部に排出孔 を備えており, 実験終了後には炉内サンプルをタッピング により排出することが可能である。実験においては, 溶融 メタルがタッピングされ, 炉内の残留スラグないし炭材が 出始めたらタッピングを停止した。

実験に用いたスラグ試料の化学組成を Table 1 に, 実験条 件を Table 2 に示す。スラグ試料は所定の塩基度 $\left(\mathrm{CaO} / \mathrm{SiO}_{2}\right.$ 重量パーセント比）となる様に実機の脱リンスラグと脱炭 スラグを混合した。スラグ試料 6 は実スラグよりも低塩基 度組成を目標としており，珪砂（ $\mathrm{SiO}_{2}$ 純度>95 mass\%) を 添加して塩基度を調整した。還元用炭材はC 純度 99 mass \% 以上の黒鉛を用い, 配合量はスラグ中の $\left(\mathrm{Fe}_{t} \mathrm{O}\right),\left(\mathrm{P}_{2} \mathrm{O}_{5}\right)$ の 還元に必要な化学量論值に対して約 10 倍とした。Fig.3に

Table 1. Chemical compositions of slag for experiments.

\begin{tabular}{|c|c|c|c|c|c|c|c|c|c|c|c|}
\hline \multirow{2}{*}{$\begin{array}{l}\text { Slag } \\
\text { sample }\end{array}$} & \multicolumn{10}{|c|}{ Slag composition (mass\%) } & \multirow{2}{*}{$\frac{\text { Slag basicity }}{(\% \mathrm{CaO}) /\left(\% \mathrm{SiO}_{2}\right)}$} \\
\hline & $\mathrm{CaO}$ & $\mathrm{SiO}_{2}$ & $\mathrm{Al}_{2} \mathrm{O}_{3}$ & $\mathrm{MgO}$ & $\mathrm{P}_{2} \mathrm{O}_{5}$ & $\mathrm{MnO}$ & T.Fe & $\mathrm{FeO}$ & $\mathrm{Fe}_{2} \mathrm{O}_{3}$ & M.Fe & \\
\hline $1-3$ & 28.72 & 18.81 & 5.18 & 4.35 & 2.02 & 4.70 & 28.50 & 20.35 & 10.60 & 5.27 & 1.53 \\
\hline 4 & 36.46 & 16.32 & 3.43 & 4.74 & 2.39 & 2.77 & 26.20 & 12.70 & 16.14 & 5.05 & 2.23 \\
\hline 5 & 26.12 & 26.57 & 4.47 & 3.43 & 2.67 & 3.45 & 26.42 & 18.71 & 8.93 & 5.61 & 0.98 \\
\hline 6 & 29.76 & 38.90 & 2.43 & 4.64 & 1.88 & 1.75 & 15.11 & 6.11 & 13.85 & 0.67 & 0.77 \\
\hline
\end{tabular}

Table 2. Experimental conditions.

\begin{tabular}{|c|c|c|c|c|c|c|c|}
\hline & \multicolumn{7}{|c|}{ Conditions } \\
\hline & \multirow{2}{*}{ Slag sample } & \multirow{2}{*}{ Sample weight } & \multirow{2}{*}{ Carbon } & \multicolumn{2}{|c|}{ Temperature } & \multirow{2}{*}{ Time } & \multirow{2}{*}{ Burner direction } \\
\hline & & & & Target & Actual & & \\
\hline \multirow{2}{*}{ Run-1 } & \multirow{6}{*}{$1-3$} & \multirow{6}{*}{$50 \mathrm{~kg}$} & \multirow{6}{*}{$33 \mathrm{~kg}$} & \multirow{2}{*}{$1623 \mathrm{~K}$} & $1603-1673 \mathrm{~K}$ & \multirow{6}{*}{$90 \mathrm{~min}$} & \multirow{2}{*}{ Direct heating } \\
\hline & & & & & Ave. : $1628 \mathrm{~K}$ & & \\
\hline \multirow{2}{*}{ Run-2 } & & & & \multirow{2}{*}{$1673 \mathrm{~K}$} & $1643-1753 \mathrm{~K}$ & & \multirow{10}{*}{ Indirect heating } \\
\hline & & & & & Ave. : $1686 \mathrm{~K}$ & & \\
\hline \multirow{2}{*}{ Run-3 } & & & & \multirow{2}{*}{$1623 \mathrm{~K}$} & $1603-1673 \mathrm{~K}$ & & \\
\hline & & & & & Ave. : $1632 \mathrm{~K}$ & & \\
\hline \multirow{2}{*}{ Run-4 } & \multirow{2}{*}{4} & \multirow{2}{*}{$50 \mathrm{~kg}$} & \multirow{2}{*}{$33 \mathrm{~kg}$} & \multirow{2}{*}{$1723 \mathrm{~K}$} & $1648-1773 \mathrm{~K}$ & \multirow{6}{*}{$120 \mathrm{~min}$} & \\
\hline & & & & & Ave. : $1708 \mathrm{~K}$ & & \\
\hline \multirow{2}{*}{ Run-5 } & \multirow{2}{*}{5} & \multirow{2}{*}{$50 \mathrm{~kg}$} & \multirow{2}{*}{$33 \mathrm{~kg}$} & \multirow{2}{*}{$1673 \mathrm{~K}$} & $1653-1710 \mathrm{~K}$ & & \\
\hline & & & & & Ave. : $1683 \mathrm{~K}$ & & \\
\hline \multirow{2}{*}{ Run-6 } & \multirow{2}{*}{6} & \multirow{2}{*}{$50 \mathrm{~kg}$} & \multirow{2}{*}{$33 \mathrm{~kg}$} & \multirow{2}{*}{$1523 \mathrm{~K}$} & $1444-1561 \mathrm{~K}$ & & \\
\hline & & & & & Ave. : $1496 \mathrm{~K}$ & & \\
\hline
\end{tabular}


Run-4実験時の温度変化と実験の流れの概略図を示す。実 験温度より $50 \mathrm{~K}$ 程度高温まで炉を予熱し，炉蓋の原料投入 孔から 5〜10 kgの炭材を投入・燃焼させることで，予め還 元䨌囲気を形成し，CO濃度が $10 \%$ に到達した時点を実験 開始時刻とした。スラグ試料および還元用炭材は粒度 5.0 $\times 10^{-3} \mathrm{~m}$ 以下に調整したものを予め混合して 10 分割し, 実験開始時刻から5 分毎に炉蓋の原料投入孔より装入し た。所定の時間経過後にバーナーを消火し，炉体下部の排 出孔より炉内サンプルを排出した。排出されない炉内残留 物は炉体が冷却された翌日に鉄製治具を用いて回収した。 回収サンプル中のスラグとメタルを磁選分離し，それぞれ の重量測定，化学組成分析を行った。なお，スラグとメタ ルの分析には代表性を持たせるために，回収したサンプル に対して縮分操作を行った後に $0.25 \times 10^{-3} \mathrm{~m}$ 以下に粉砕 し，分析に供した。

\section{3. 実験結果}

\section{$3 \cdot 1$ スラグ中 $\left(\mathrm{Fe}_{t} \mathrm{O}\right)$ の還元}

スラグ中の $\left(\mathrm{Fe}_{t} \mathrm{O}\right)$ の還元割合に及ぼす温度とスラグ塭 基度の影響をそれぞれFig.4,Fig.5に示す。Fig.4から分か る様に，処理温度が高いほど多くの酸化鉄が還元され，多 くの金属Feが得られる。一方で, Fig.5に抏いて，同等の処 理温度である Run-2, 4, 5 の結果を比較すると，スラグ塩基 度の影響は小さいことが分かる。

Fig.4, 5 に示した様に, Run 1-3の中でRun-1の酸化鉄還 元率が若干低い。この理由として，バーナー火炎を $\mathrm{LPG}$, 空気, 純酸素で形成しており，バーナー火炎がサンプルに 直接当たる時点ではLPGが完全燃焼しておらず，燃焼用の 空気ないし純酸素による酸化が生じたためだと考えられ る。

処理温度の低いRun-6を除き，実験後に炉体下部の排出 孔から溶融メタルをタッピングできた。例として Run-4の

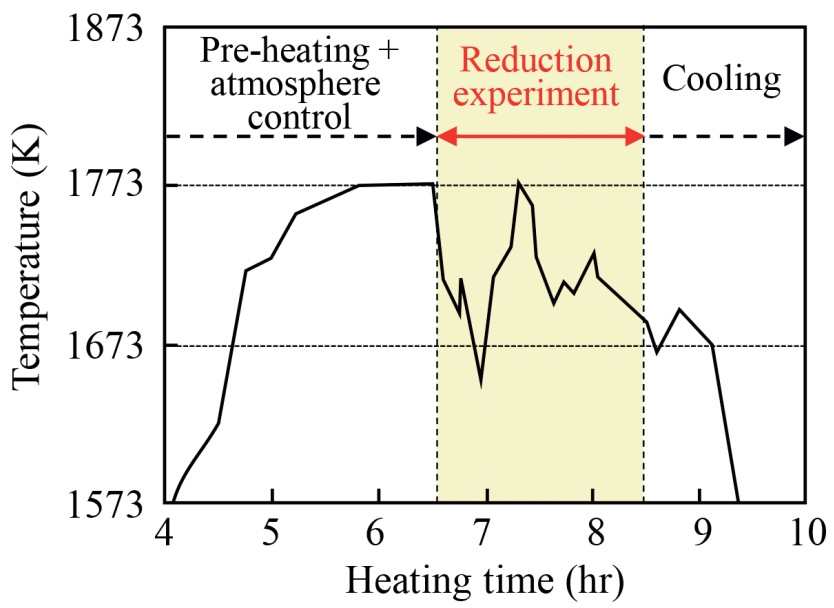

Fig. 3. Temperature transition during experiment (Run-4) (Online version in color.)
タッピング後の写真を Fig.6に示す。Fig.6より分かる様に, ほぼメタルのみがタッピングされた。これは, 炉体の転動 により炉内で溶融スラグと溶融メタルそれぞれが凝集し， 比重差による分離が進行した結果，比重の大きいメタルの みが炉体下部の排出孔からタッピングされたと考えられ る。すなわち，キルンの様な転動可能な装置で製鋼スラグ を高温還元することで，スラグと分離した状態でメタルを 回収可能と考えられる。なお，処理温度の低いRun-6につ いては，排出孔からのタッピングは出来なかったが，Fig.7 に示す様に実験後に回収した炉内スラグには数 $\mathrm{mm}$ 程度の 粒状メタルが多数存在した。このような差が生じた理由と して, Run-6の条件ではメタル，スラグ共に溶融しておら ず，メタルがスラグに取り込まれたまま凝集が十分に進行 しなかったと考えられる。

\section{$3 \cdot 2$ スラグ中 $\left(\mathrm{P}_{2} \mathrm{O}_{5}\right)$ の還元}

実験前のスラグに含まれるリンの重量を 1 とした時の,

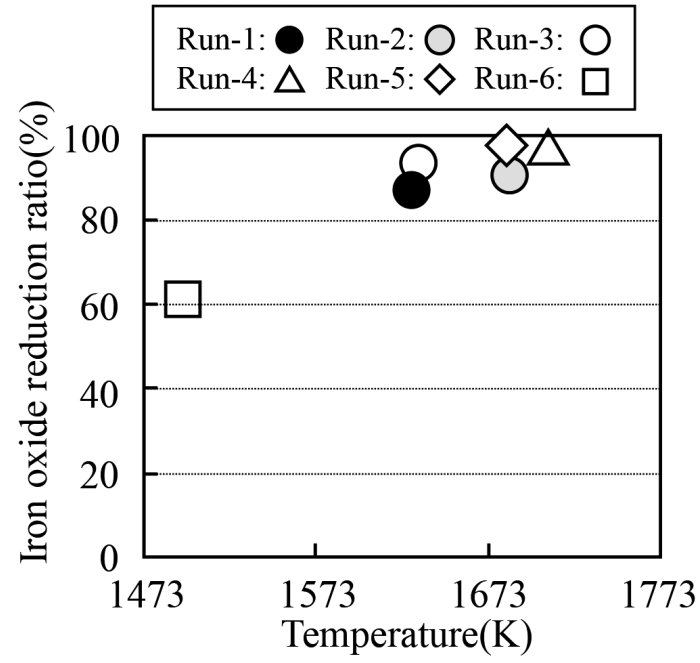

Fig. 4. Relationship between temperature and $\left(\mathrm{Fe}_{t} \mathrm{O}\right)$ reduction ratio.

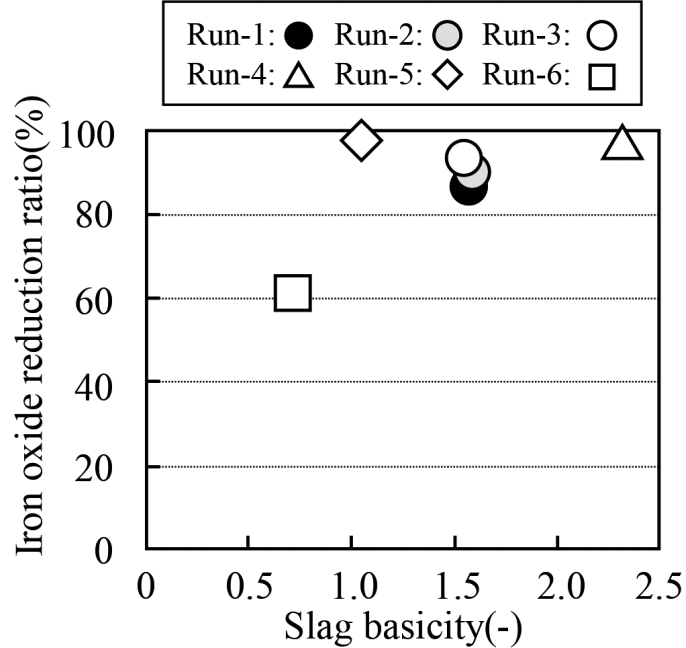

Fig. 5. Relationship between slag basicity and $\left(\mathrm{Fe}_{t} \mathrm{O}\right)$ reduction ratio. 
実験後のリンのマスバランスをFig.8に示す。スラグ中に $\left(\mathrm{P}_{2} \mathrm{O}_{5}\right)$ として残留しているリン，メタル Fe中に取り込ま れたリン，いずれでもない不明分に分別した。この不明分

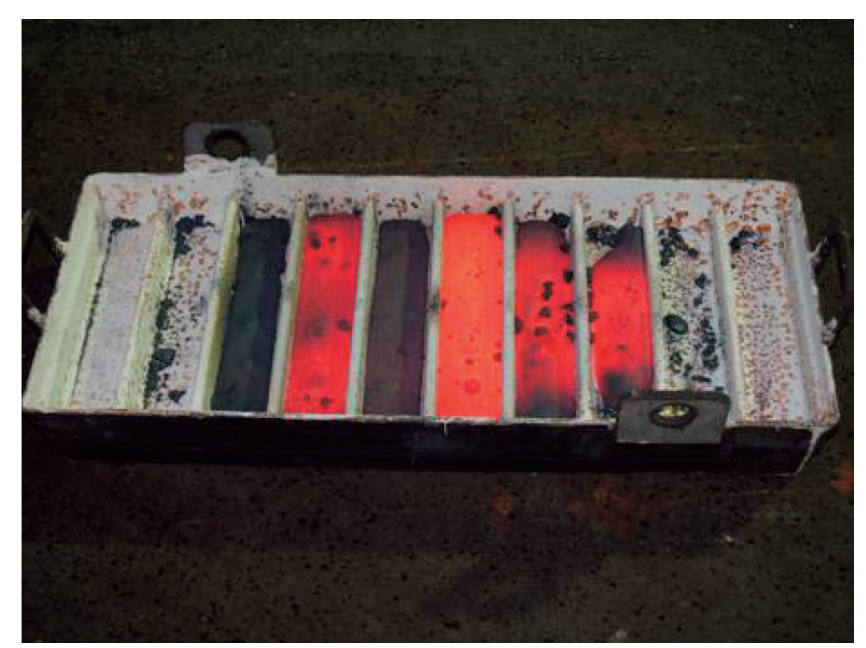

Fig. 6. Image of tapped metal (Run-4). (Online version in color.)

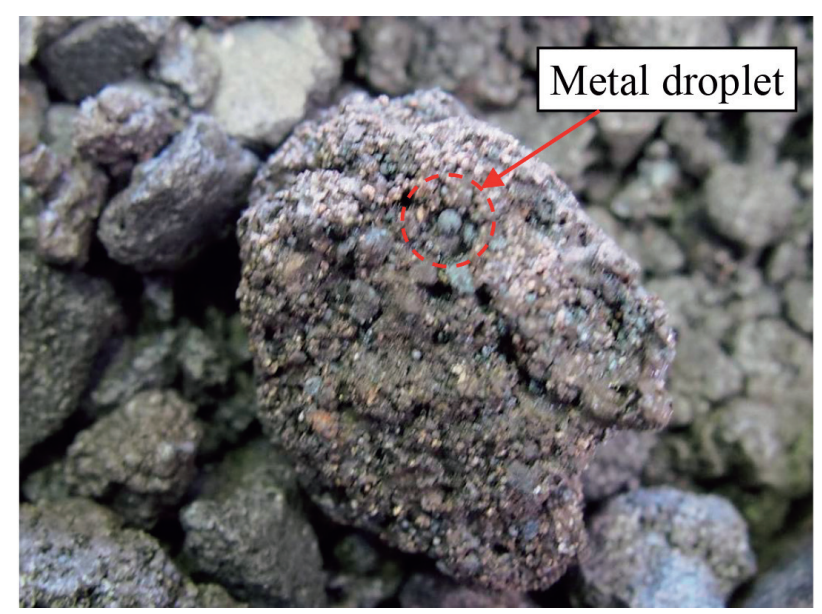

Fig. 7. Image of remained slag with metal droplets (Run-6). (Online version in color.)

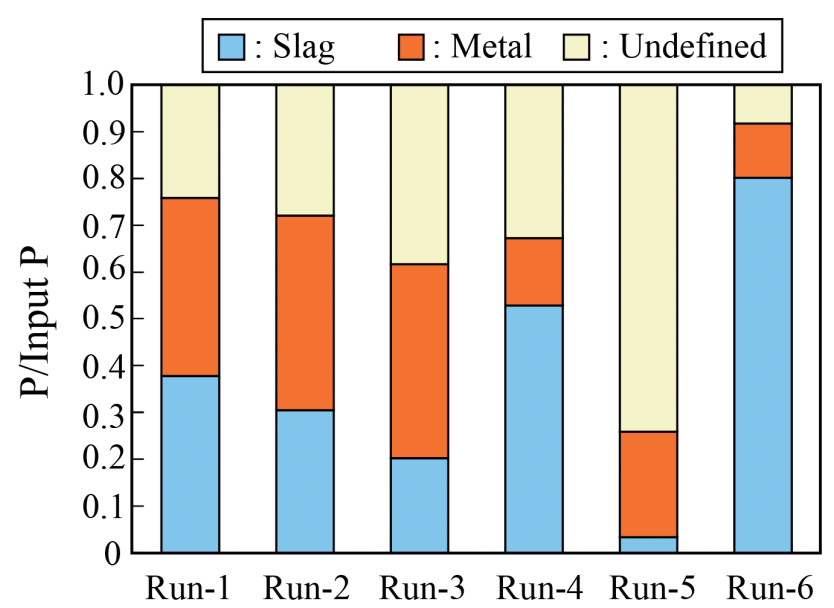

Fig. 8. Mass balance of $\mathrm{P}$ in experiments. (Online version in color.)

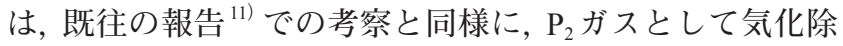
去されたリンだと考えられる。

スラグ中の $\left(\mathrm{P}_{2} \mathrm{O}_{5}\right)$ の還元割合に及ぼす温度とスラグ塭 基度の影響をそれぞれFig.9, Fig.10に示す。処理温度の低 いRun-6を除き，Fig.9に示す温度影響が不明瞭である一 方, Fig.10に示す様にスラグ塩基度が小さいほど $\left(\mathrm{P}_{2} \mathrm{O}_{5}\right)$ の 還元割合が高いことが分かる。

\section{4. 考察}

\section{$4 \cdot 1$ 気化脱リンに及ぼす生成メタル重量の影響}

実験後のメタル Fe重量と不明リン率の関係を Fig.11に 示す。メタル Fe 重量はサンプルとして装入したスラグ中の $\mathrm{Fe}$ 重量に Fig.4, 5 に示す酸化鉄の還元割合を掛けた值であ り, タッピングしたメタルと炉内に残留した粒鉄の合計重 量である。ここで, Run-6は他の実験よりも低温であり, 還

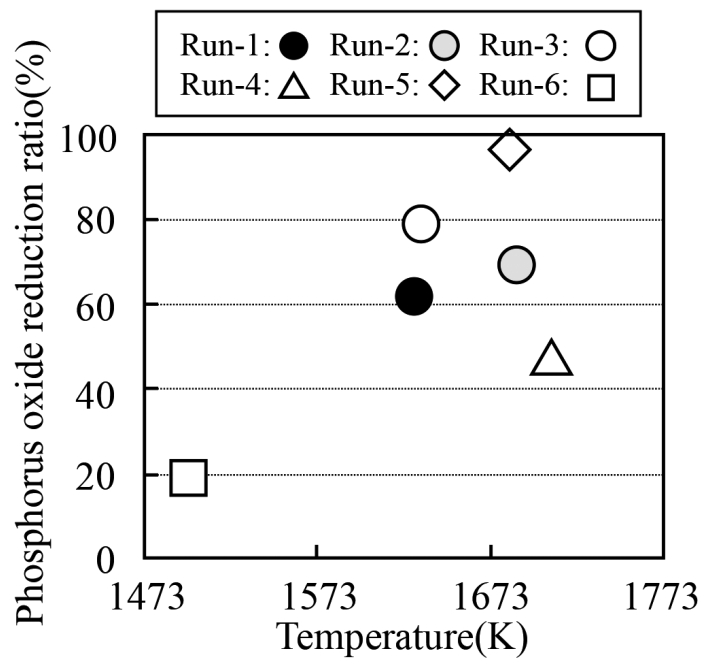

Fig. 9. Relationship between temperature and $\left(\mathrm{P}_{2} \mathrm{O}_{5}\right)$ reduction ratio.

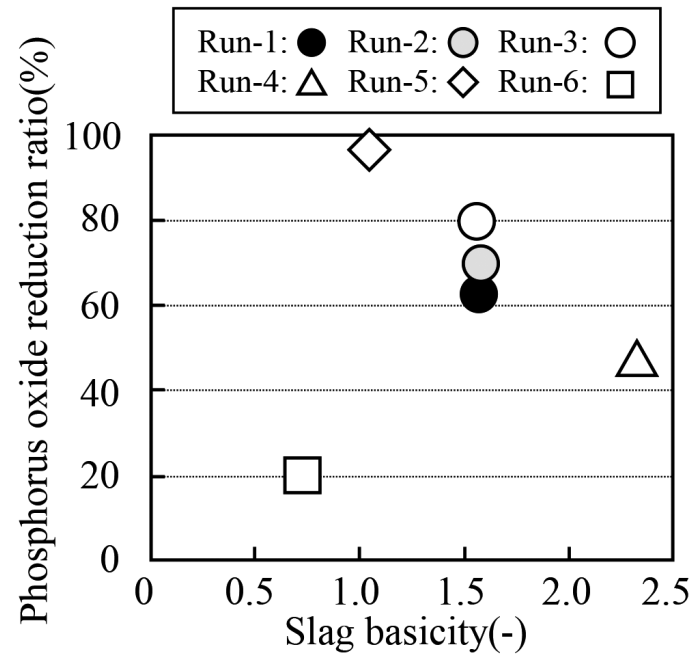

Fig. 10. Relationship between slag basicity and $\left(\mathrm{P}_{2} \mathrm{O}_{5}\right)$ reduction ratio. 
元が十分に進行しなかった結果, 実験後のメタル Fe重量が $5 \mathrm{~kg}$ 程度と低位であったのでグラフより除外した。また, グラフ中の数字は各実験後メタルのリンの質量濃度であ る。

Run-1, 2, 3 を比較すると，同等のスラグ塩基度において メタル Fe重量が増加するほど不明リン率が増加している。 実験後メタル中のリン濃度は $1.58 \sim 1.68 \mathrm{mass} \%$ で同等であ り，リンのマスバランスを考えると，メタル Fe重量が増加 してメタル Feに含まれるリンが増加するほど不明リン率 は減少するはずであることと相反する。

また, 式 (1) に示す $\mathrm{P}_{2}$ ガスの溶鉄への溶解反応 ${ }^{16)}$ の標準 ギブズ自由エネルギー変化は式 (2) で表される。式 (2)よ り，温度が高いほどメタル中のリンが減少し，気化除去さ れる割合が増加すると考えられる。

$$
1 / 2 \mathrm{P}_{2}(\mathrm{~g})=\underline{\mathrm{P}}
$$

$$
\Delta G_{1}^{\circ}=-157700+5.4 T(\mathrm{~J} / \mathrm{mol})
$$

Run-2 はRun-1, 3 よりも高温での実験であり，定性的に は不明リン率が増加すると考えられるが, Fig.11より分か る様にその様な結果とはなっていない。

Run-4 は高塩基度, 高温での実験であり， $\left(\mathrm{P}_{2} \mathrm{O}_{5}\right)$ の還元 割合は他の実験よりも低位で，かつ実験後のメタル Fe 重量 も低位だが，不明リン率は同等となった。定性的には高塩 基度条件では不明リン率が低下，高温条件では不明リン率 が増加すると考えられるが，Run-4においてどちらの条件 の影響が大きく現れたかは不明である。

Run-5 は低塩基度，高温での実験であり，どちらの条件 も定性的に気化脱リン促進に有効だと考えられ，同等のメ タル Fe重量の Run-2よりも高い不明リン率であることは妥 当な結果だと考えられる。

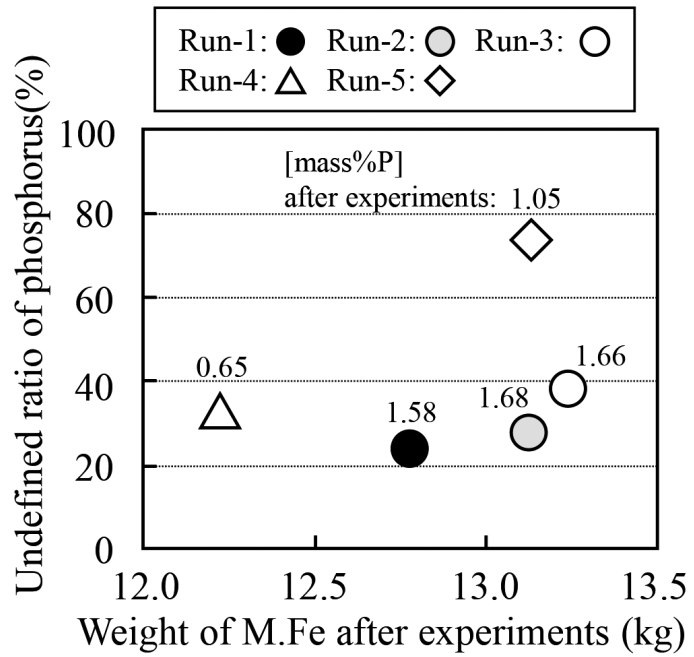

Fig. 11. Relationship between weight of M. Fe and undefined ratio of phosphorus.

\section{$4 \cdot 2$ スラグからの気化脱リン条件}

$4 \cdot 1$ で述べた様に, 実験後のメタル Fe重量のみでは不 明リン率を説明することは出来ない。そこで, 前報 ${ }^{11)}$ と同 様に, スラグの組成, 還元温度, 酸素ポテンシャルの影響 をまとめて表す指標としてスラグ - メタル間の平衡リン分 配比 $L_{P}$ を用いて考察を行った。

前報 ${ }^{11)}$ の式 (15) を用いて計算した $\log \mathrm{L}_{\mathrm{p}}$ と, 不明リン率 の関係を Fig. 12 に示す。 $\log \mathrm{L}_{\mathrm{p}}$ と不明リン率には良い相関関 係が認められ, $\log \mathrm{L}_{\mathrm{P}}$ の低下に伴い不明リン率は向上する。 図中には前報 ${ }^{11)}$ のるつぼ実験結果の範囲を合わせて示す が，今回の結果と良い一致を示している。このことから， ロータリーキルンを模擬した実験においても, 不明リン率 は $\log \mathrm{L}_{\mathrm{P}}$ で整理可能なことが明らかとなった。

\section{$4 \cdot 3$ メタルの凝集に及ぼす処理方法の影響}

前報 ${ }^{11)}$ におけるるつぼ実験と本研究のロータリーキル ン模擬実験に打いて，還元された鉄の内，凝集してメタル 塊として回収された重量割合をFig.13に示す。ここで，前 報の実験の内, $\mathrm{Fe}_{t} \mathrm{O}$ 濃度が低いスラグでの実験では還元 された Fe量が少なく，わずかな実験の誤差によりグラフ の縦軸の值が大きく変動し得るので除外した。また，図中 には熱力学計算ソフト FactSageにより求めたスラグの液 相率の計算線を併記する。計算スラグ組成は，還元後スラ グ組成を想定して $\left(\operatorname{mass} \% \mathrm{Al}_{2} \mathrm{O}_{3}\right)=8,(\operatorname{mass} \% \mathrm{MgO})=6$, $(\operatorname{mass} \% \mathrm{MnO})=6,(\operatorname{mass} \% \mathrm{FeO})=1,\left(\operatorname{mass} \% \mathrm{Fe}_{2} \mathrm{O}_{3}\right)=1$, $\left(\operatorname{mass} \% \mathrm{P}_{2} \mathrm{O}_{5}\right)=1$ とし，スラグ塩基度が 1.0, 1.5, 2.0 となる 様に $\operatorname{mass} \% \mathrm{CaO})$ と $\left(\mathrm{mass} \% \mathrm{SiO}_{2}\right)$ を決定した。

Fig.13より分かる様に, るつぼ実験とキルン模擬実験の 両者のメタル凝集挙動の差を定量的に考察するのは困難で ある。一方で，定性的にはスラグの塩基度 $\mathrm{C} / \mathrm{S}$ が小さいほ ど還元されたメタルの凝集率が高いことが分かる。これは 還元後のスラグの融点が低く，液相率が高かったことでス ラグ中のメタル移動が容易となり，分離が促進されたと考

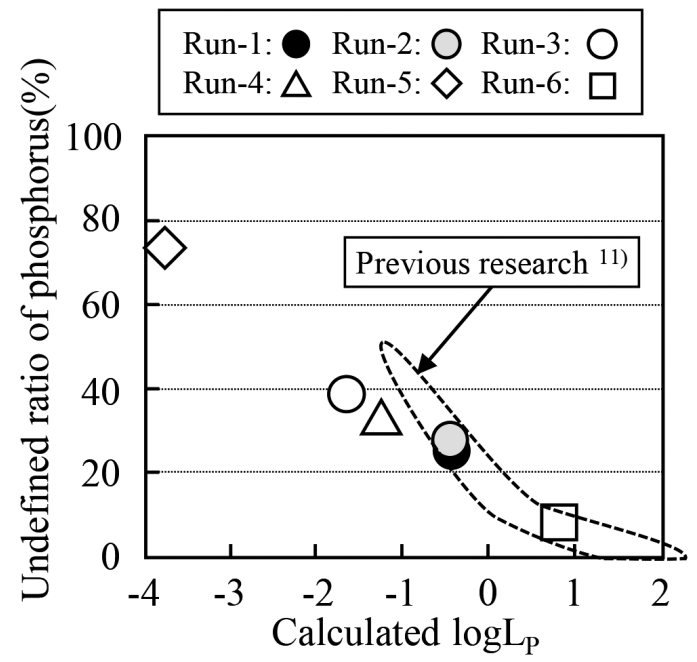

Fig. 12. Relationship between $\log L_{P}$ and undefined ratio of phosphorus. 
えられる。なお, Fig.13には還元後を想定して低 $\mathrm{Fe}_{t} \mathrm{O}$ 濃度 での計算結果を示しているが, 処理前を想定した $\mathrm{Fe}_{t} \mathrm{O}$ 濃度 30 mass\% \%で同様に計算しても，同じ温度では塩基度が小 さいほど計算液相率の割合が高かった。

このことから，還元前〜還元後において高温で溶融ない し半溶融したスラグの割合がメタル凝集に影響したと考え られる

\section{$4 \cdot 4$ 鉄, リンの分離性に及ぼす処理方法の影響}

$4 \cdot 2$ と同様に, 前報 ${ }^{11)}$ の式 (15) を用いて計算した $\log L_{\mathrm{P}}$ と, 実験後のメタルおよびスラグ中の $\mathrm{P}$ 濃度から求めた実 績 $\log \mathrm{L}_{\mathrm{P}}$ の関係を Fig.14に示す。罒中には前報 ${ }^{11)}$ のるつぼ 実験の結果も記載している。

Fig.14より分かる様に, キルン模擬実験では「計算 $\mathrm{L}_{\mathrm{P}}<$ 実績 $\left.\mathrm{L}_{\mathrm{P}}\right\rfloor$, るつぼ実験では「計算 $\mathrm{L}_{\mathrm{P}}>$ 実績 $\mathrm{L}_{\mathrm{P}} 」$ とう傾向 が見て取れる。計算 $\mathrm{L}_{\mathrm{P}}$ よりも実績 $\mathrm{L}_{\mathrm{P}}$ が大きくなる理由と して以下の2つが考えられる。

(1) $\left(\mathrm{P}_{2} \mathrm{O}_{5}\right)$ の還元が不十分で, スラグ/メタル平衡に到達 していない

(2) $\left(\mathrm{P}_{2} \mathrm{O}_{5}\right)$ の還元前にスラグ/メタル分離が進行し，スラ グ/メタル界面が減少してメタルヘのリン移行が抑制 された。

(1)については, Fig.9, 10に示す様に, Run-6を除いて $40 \%$ 以上, 特にRun-5においては $96 \%$ の $\left(\mathrm{P}_{2} \mathrm{O}_{5}\right)$ が還元され ており,るつぼ実験と比べて $\left(\mathrm{P}_{2} \mathrm{O}_{5}\right)$ の還元が不十分とは 考えづらい。

(2) については，スラグ中のリンのメタルへの移行が抑 制された場合, スラグから気相へのリン除去が促進される と考えられる。これは $4 \cdot 2 て ゙$ 述べた様に, 計算 $\log \mathrm{L}_{\mathrm{P}}$ が小 さいほど不明リン率が増加していることと合致する。

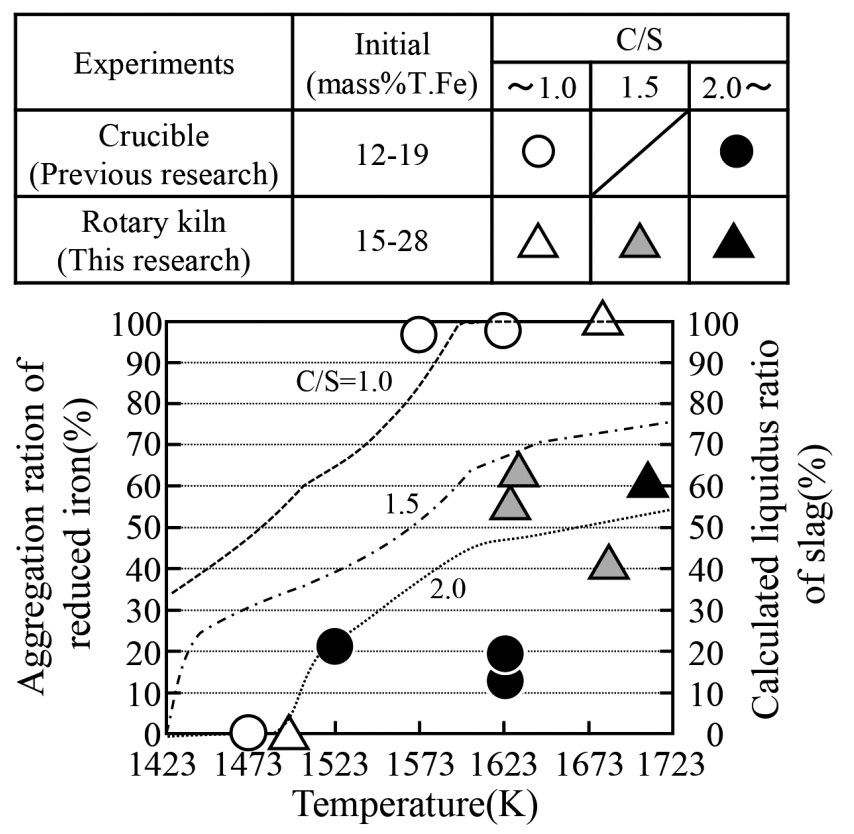

Fig. 13. Aggregation ratio of reduced iron.
一方で，るつぼ実験の初期スラグ中 T.Fe濃度および塩基 度の低い条件 (図中〉) においては，キルン実験と同等の 計算 $\mathrm{L}_{\mathrm{P}}$ にも関わらず実績 $\mathrm{L}_{\mathrm{P}}$ は2 桁程度小さい。これは初期 スラグ中 T.Fe濃度が低く, メタル生成量が少ない所にスラ グに含まれるリンの約 $40 〜 80 \%$ が移行した結果, メタル中 リン濃度が 10 mass\%以上と高くなったためだと考えられ る。

これらのことから, ロータリーキルンの様な試料転動に よる鉛直方向の摚拌が生じる設備で製鋼スラグの高温還元 を行うことで, $\left(\mathrm{P}_{2} \mathrm{O}_{5}\right)$ の還元前にスラグ/メタル分離が進 行してスラグ/メタル界面が減少し, メタルへのリン移行 抑制と気相へのリン除去促進が可能だと考えられる。

なお, Fig.14の様な整理を行う場合, 計算 $\mathrm{L}_{\mathrm{P}}$ の取り扱い に注意が必要である。詳細は前報に記載した通りだが，今 回用いた計算 $\mathrm{L}_{\mathrm{P}}$ は, Suito and Inoue ${ }^{17)}$ によるフォスフェイ トキャパシティの式と, $\mathrm{P}_{2}$ ガスの溶鉄への溶解反応の標 準ギブズ自由エネルギー変化 ${ }^{16)}$ および正則容体モデル ${ }^{18)}$ により求めた $\mathrm{Fe}_{t} \mathrm{O}$ 活量から計算される酸素分圧から計算 した值である。Suito and Inoueのフォスフェイトキャパシ ティは1823〜 $1923 \mathrm{~K}$ の溶鋼温度で測定されたものであり, 本研究の実験温度 1473 1708 Kに適用できるかは定かで はない。

一方で, 溶銑予備処理温度である 1473〜 1673 Kでスラグ /メタル間のリン分配比の測定 ${ }^{19-22)}$ が行われているが，こ の温度帯では $\mathrm{CaO}-\mathrm{SiO}_{2}-\mathrm{Fe}_{t} \mathrm{O}$ 系スラグには広い固液共存領 域が存在するため, 完全に溶融している $\mathrm{Fe}_{t} \mathrm{O}$ 濃度 $\geqq$ 約 20 mass $\%$ の組成あるいは融牏として $\mathrm{CaF}_{2}$ が添加された系の

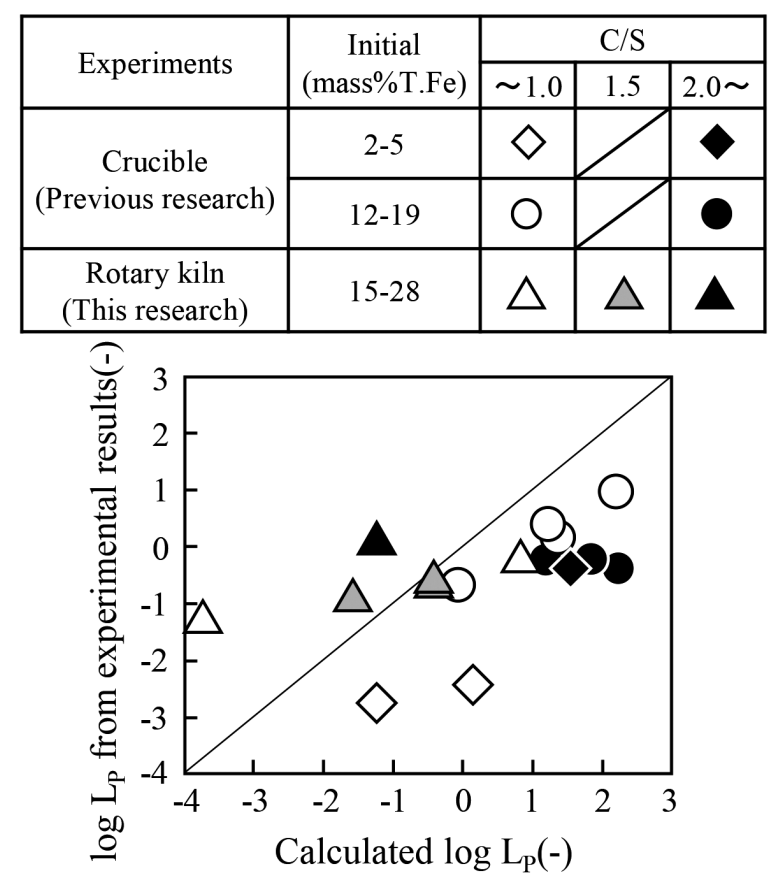

Fig. 14. Relationship between calculated $L_{P}$ and $L_{P}$ from experimental results. 
データに限定される。

溶鋼温度, 溶銑温度のいずれのリン分配のデータも本研 究の条件に直接適用できる訳ではないが，(1)溶鋼温度，低 $\mathrm{Fe}_{t} \mathrm{O}$ 濃度での測定データを低温側に外挿, (2)溶銑温度, 高 $\mathrm{Fe}_{t} \mathrm{O}$ 濃度での測定データを低 $\mathrm{Fe}_{t} \mathrm{O}$ 濃度に外挿，の2通りを 評価したところ, (1)の方が計算 $\mathrm{L}_{\mathrm{P}}$ と実績 $\mathrm{L}_{\mathrm{P}}$ が近い值となつ たため，本研究では(1)の評価方法を採用した。

\section{5. 結言}

製鋼スラグから鉄とリンの分離挙動を評価するため, ロータリーキルンを模擬した数十 $\mathrm{kg}$ 規模の実験を行い, 以 下の結論を得た。

（1）スラグ塩基度 $=1.0 〜 2.3$ ，温度 $1630 \sim 1710 \mathrm{~K}$ で製鋼ス ラグを高温還元することにより，スラグ中 $\left(\mathrm{Fe}_{t} \mathrm{O}\right)$ の $87 \%$ 以上を還元し，炉体下部の排出孔よりメタル Feを タッピングすることが出来た。

（2）実験後のメタルFe重量が増加すると，メタル中のリン の量が増えて気化除去されるリンの割合が減ると考え られるが，実験結果はその様にならなかった。

（3）スラグ組成，還元温度，酸素ポテンシャルの影響をま とめて表す指標として平衡リン分配比 $\mathrm{L}_{\mathrm{p}}$ を用いて整 理したところ，前報と同様に $\log \mathrm{L}_{\mathrm{P}}$ の低下に伴い気化 除去されるリンの割合が増加した。

（4）キルン模擬実験において計算 $\mathrm{L}_{\mathrm{P}}<$ 実績 $\mathrm{L}_{\mathrm{P}}$ であった。こ の理由として, $\left(\mathrm{P}_{2} \mathrm{O}_{5}\right)$ の還元前にスラグ/メタル分離 が進行し，スラグ/メタル界面が減少してメタルへの リン移行が抑制されたと考えられる。

\section{謝辞}

本研究の一部は, 平成 21 年度国立研究開発法人新エネル ギー・産業技術総合開発機構（NEDO）「製鋼スラグ資源化 技術のためのりん分離回収に関する事前研究」にて助成を 受けて行った成果である。

\section{文献}

1 ) H.Yahata, Y.Kurose, H.Okuda, K.Oshima and A.Aoyagi: CAMP$I S I J, 8$ 8(1995), 1101 (in Japanese).

2 ) M.Kimura, S.Nakajima, T.Mimura, I.Hoshikawa, R.Ono and K.Semura: Kobe Steel Eng. Rep., 51(2001), 50 (in Japanese)

3 ) Development Trends and Subjects for Steelmaking Slag Minimization, Final Report of Steelmaking Slag Minimization Working Group, ISIJ, Tokyo, (1999), (in Japanese).

4 ) S.Shiomi, N.Sano and Y.Matsushita: Tetsu-to-Hagané, 63(1977), 1520 (in Japanese).

5 ) S.Takeuchi, N.Sano and Y.Matsushita: Tetsu-to-Hagané, 66(1980), 2050 (in Japanese).

6 ) K.Nagata: Reduction of Steelmaking Slag Generation and Utilization of Steelmaking Slag, Final Report of Working Group for Basic and Applied Research for Steelmaking Slag, ISIJ, Tokyo, (1997), 49 (in Japanese).

7 ) K.Morita, M.Guo, N.Oka and N.Sano: J. Mater. Cycles Waste Manag., 4(2002), 93 (in Japanese)

8 ) S.Toishi and K.Itoh: CAMP-ISIJ, 17(2004), PS-1 (in Japanese).

9 ) H.Kubo, K.Matsubae and T.Nagasaka: Tetsu-to-Hagané, 95(2009), 300 (in Japanese).

10) A.Matsui, K.Nakase, N.Kikuchi, Y.Kishimoto, K.Takahashi and K.Ishida: Tetsu-to-Hagané, 97(2011), 10 (in Japanese).

11) K.Nakase, A.Matsui, N.Kikuchi and Y.Miki: Tetsu-to-Hagané, 102(2016), 485 (in Japanese).

12) T.Harada, H.Hirata, T.Arai, T.Toh and T.Yamada: ISIJ Int., 58(2018), 1934.

13) T.Harada, H.Hirata, T.Arai, T.Toh and C.Shuto: ISIJ Int., 58(2018), 1943.

14) I.Tetsuyama: Sumitomo Heavy Ind. Tech. Rev., 158(2005), 19 (in Japanese).

15) I.Tetsuyama and I.Kawakami: Sumitomo Heavy Ind. Tech. Rev., 167(2008), 5 (in Japanese).

16) Steelmaking Data Sourcebook, Revised ed., The 19th Committee on Steelmaking, The Japan Society for the Promotion of Science, Tokyo, (1984)

17) H.Suito and R.Inoue: ISIJ Int., 35(1995), 258

18) S.Ban-ya: ISIJ Int., 33(1993), 2.

19) K.Iwasaki, N.Sano and Y.Matsushita: Tetsu-to-Hagané, 67(1981), 536 (in Japanese).

20) K.Ito and N.Sano: Tetsu-to-Hagané, 69(1983), 1747 (in Japanese).

21) M.Muraki, H.Fukushima and N.Sano: Tetsu-to-Hagané, 71(1985), 693 (in Japanese)

22) J.Im, K.Morita and N.Sano: ISIJ Int., 36(1996), 517. 